\title{
Evaluation of real-life use of Point-Of-Care Rapid Antigen TEsting for SARS-CoV-2 in schools (EPOCRATES)
}

Ana C. Blanchard, MD MSc ${ }^{1}$, Marc Desforges, $\mathrm{PhD}^{2,3}$, Annie-Claude Labbé, $\mathrm{MD}^{3,4}$, Cat Tuong Nguyen, $\mathrm{MD}, \mathrm{PhD}^{5}$, Yves Petit, $\mathrm{MSc}^{6}$, Dominic Besner, $\mathrm{BEd}^{7}$, Kate Zinszer, $\mathrm{PhD}^{8}$, Olivier Séguin, $\mathrm{PhD}^{5}$, Zineb Laghdir, $\mathrm{MSc}^{9}$, Kelsey Adams, $\mathrm{MScPH}^{9}$, Marie-Ève Benoit, $\mathrm{MSc}^{9}$, Geneviève Leduc ${ }^{9}$, Jean Longtin, $\mathrm{MD}^{10}$, Ioannis Ragoussis, $\mathrm{PhD}^{11}$, David L. Buckeridge, MD $\mathrm{PhD}^{12}$, Caroline Quach, MD MSc ${ }^{2,3}$

Affiliations: ${ }^{1}$ Division of Infectious Diseases, Department of Pediatrics, CHU Sainte-Justine, Université de Montréal, Montréal (QC), Canada. ${ }^{2}$ Clinical Department of Laboratory Medicine, CHU Sainte-Justine, Montréal (QC), Canada. ${ }^{3}$ Department of Microbiology, Infectious Diseases and Immunology, Université de Montréal, Montreal (QC), Canada. ${ }^{4}$ Division of Infectious Diseases, Department of Medicine, Centre intégré universitaire de santé et de services sociaux (CIUSSS) de l'Est-de-l'Île-de-Montréal, Montréal (QC), Canada. ${ }^{5}$ Direction régionale de santé publique, CIUSSS du Centre-Sud-de-l'île-de-Montréal, Montréal (QC), Canada. ${ }^{6}$ Pensionnat du Saint-Nom-de-Marie, Montréal (QC), Canada. ${ }^{7}$ École secondaire Calixa-Lavallée, Montréal (QC), Canada. ${ }^{8}$ École de santé publique de l'Université de Montréal, Université de Montréal, Montréal, Quebec. ${ }^{9}$ Research Center, CHU Sainte-Justine, Montréal (QC), Canada. ${ }^{10}$ Clinical Department of Laboratory Medicine, CHU de Québec, Quebec City, Quebec. ${ }^{11}$ McGill Genome Center, McGill University, Montréal (QC), Canada. ${ }^{12}$ Department of Epidemiology, Biostatistics and Occupational Health, McGill University, Montréal (QC), Canada

Address correspondence to: Caroline Quach, Department of Microbiology. CHU SainteJustine 3175 Chemin de la Côte-Sainte-Catherine, Montréal, Quebec, Canada, H3T 1C5 c.quach@umontreal.ca

Short title: Rapid antigen testing for SARS-CoV-2 in schools

Conflict of Interest Disclosures: The authors declare that they have no known competing financial interests or personal relationships that could have appeared to influence the work reported in this paper.

Funding: Québec Ministry of Health and Social Services

Role of Funder: The study sponsor did not have a role in study design, in interpretation of data, writing of the report or decision to submit the paper for publication.

Abbreviations: ABM (agent-based model), Ct (cycle threshold), COVID-19 (Coronavirus disease 2019), D (day), ESCL (École Secondaire Calixa-Lavallée), LOD (limit of detection), PCR (polymerase chain reaction), PSNM (Pensionnat du Saint-Nom-de-Marie), RADT (rapid antigen detection test), SARS-CoV-2 (Severe acute respiratory syndrome coronavirus 2), TAT (turnaround time)

NOTE: This preprint reports new research that has not been certified by peer review and should not be used to guide clinical practice. 1 
medRxiv preprint doi: https://doi.org/10.1101/2021.10.13.21264960; this version posted January 23, 2022. The copyright holder for this preprint

(which was not certified by peer review) is the author/funder, who has granted medRxiv a license to display the preprint in perpetuity.

It is made available under a CC-BY-NC-ND 4.0 International license.

Table of Contents Summary: Rapid antigen tests were compared to standard PCR to diagnose SARS-CoV-2 infections in high-school students. They performed better in symptomatic individuals.

What's Known on This Subject

Rapid antigen detection tests (RADT) are often used to diagnose respiratory pathogens at the point-of-care. Their performance characteristics vary, but they usually have high specificity and moderate sensitivity compared with PCR.

\section{What This Study Adds}

RADT sensitivity ranged from $28.6 \%$ in asymptomatic individuals to $83.3 \%$ in symptomatic individuals. Return to school after 7 days of quarantine was safe in exposed students. Secondary cases were identified in $28 \%$ of classes with an index case. 
medRxiv preprint doi: https://doi.org/10.1101/2021.10.13.21264960; this version posted January 23, 2022. The copyright holder for this preprint

(which was not certified by peer review) is the author/funder, who has granted medRxiv a license to display the preprint in perpetuity.

It is made available under a CC-BY-NC-ND 4.0 International license.

\section{Authors contribution statement:}

Caroline Quach conceptualized and designed the study, acquired funding, carried out the data analysis and drafted the initial manuscript.

Marc Desforges, Annie-Claude Labbé, Cat Tuong Nguyen, Kate Zinszer, Jean Longtin, Ioannis Ragoussis and David L. Buckeridge conceptualized and designed the study.

Kelsey Adams, Marie-Ève Benoit collected data and managed and coordinated the research project on site.

Yves Petit, Dominic Besner, Zineb Laghdir, Geneviève Leduc managed and coordinated the research project on site.

Ana C. Blanchard carried out the data analysis and drafted the initial manuscript.

Olivier Séguin carried out the data analysis.

All authors critically reviewed, revised the manuscript and approved the final manuscript as submitted and agree to be accountable for all aspects of the work. 


\begin{abstract}
1 Abstract (246 words)
3 Background: We evaluated the use of rapid antigen detection tests (RADT) for the diagnosis of 4 severe acute respiratory syndrome coronavirus 2 (SARS-CoV-2) infection in school settings to 5 determine RADT's performance compared to PCR.

6 Methods: In this real-world, prospective observational cohort study, high-school students and

7 staff were recruited from two high-schools in Montreal (Canada) and followed from January $25^{\text {th }}$

8 to June $10^{\text {th }}, 2021$. Twenty-five percent of asymptomatic participants were tested weekly by

9 RADT (nasal) and PCR (gargle). Class contacts of cases were tested. Symptomatic participants

10 were tested by RADT (nasal) and PCR (nasal and gargle). The number of cases and outbreaks

11 were compared to other high schools in the same area.

12 Results: Overall, 2,099 students and 286 school staff members consented to participate. The

13 overall RADT's specificity varied from 99.8 to $100 \%$, with a lower sensitivity, varying from

$1428.6 \%$ in asymptomatic to $83.3 \%$ in symptomatic participants. Secondary cases were identified

15 in 10 of 35 classes. Returning students to school after a 7-day quarantine, with a negative PCR

16 on D6-7 after exposure, did not lead to subsequent outbreaks. Of cases for whom the source was

17 known, 37 of $57(72.5 \%)$ were secondary to household transmission, 13 (25\%) to intra-school

18 transmission and one to community contacts between students in the same school.

19 Conclusion: RADT did not perform well as a screening tool in asymptomatic individuals.

20 Reinforcing policies for symptom screening when entering schools and testing symptomatic

21 individuals with RADT on the spot may avoid subsequent significant exposures in class.
\end{abstract}


medRxiv preprint doi: https://doi.org/10.1101/2021.10.13.21264960; this version posted January 23, 2022. The copyright holder for this preprint (which was not certified by peer review) is the author/funder, who has granted medRxiv a license to display the preprint in perpetuity.

It is made available under a CC-BY-NC-ND 4.0 International license.

\section{4}

25

26

27

45 We aimed: 1) to determine the performance characteristics of RADT for SARS-CoV-2 compared

\section{Background}

Timely diagnosis of infection enables outbreak control through rapid isolation of index cases and subsequent contact tracing $(1,2)$. Diagnosis of severe acute respiratory syndrome coronavirus 2 (SARS-CoV-2) infection is predominantly based on polymerase chain reaction (PCR), which has a turnaround time (TAT) of 24-48 hours. Rapid antigen detection tests (RADT) are inexpensive and can be used at the point-of-care. They usually have high specificity and moderate sensitivity compared with PCR (3-6). Given their rapid TAT, RADT allow for efficient triage and management of exposed individuals (7). The potential use of RADT is especially relevant in schools, where COVID-19 outbreaks can interrupt in-person teaching and negatively impact learning (8-11).

RADT perform best in the early stages of infection, when viral load is generally high (12-15). Reported RADT sensitivity ranges from $28.9 \%$ to $98.3 \%$, with improved RADT sensitivity in samples with high viral loads and in symptomatic individuals $(16,17)$. The usual limits of detection (LOD) for PCR is 600-1000 viral RNA copies/ml, whereas RADT usually have LOD 2-3 logs higher $\left(10^{5}\right.$ to $\left.10^{6}\right)(18)$. Many studies have indicated the importance of high viral load dynamics with infectiousness $(19,20)$. For each unit increase in Ct value, the odds of recovering infectious virus decreased by 0.67 , being under $10 \%$ when Ct-values were $>\square 35$. Ct values of 17 to 32 corresponded to $10^{5}$ and $10^{1}$ SARS-CoV-2 RNA copies/ $\mu \mathrm{L}$, respectively (21). 


\section{Methods}

\section{Participating population}

50 The study was conducted in two high schools of Montreal. Pensionnat du Saint-Nom-de-Marie

51 (PSNM) is a private school, with most students from native-born affluent families. École

52 secondaire Calixa-Lavallée (ESCL) is a public school where students are predominantly from

53 first-generation immigrant communities. Both schools followed the Ministry of Education

54 recommendations, by forming "classroom bubbles". Masks were mandatory as of October $8^{\text {th }}$,

55 2020. Students were $\sim 30 /$ class and seated three feet apart. School staff were invited to

56 participate. Vaccination began April $9^{\text {th }}, 2021$ in adults and May $25^{\text {th }}, 2021$ for children $\geq 12$

57 years.

$59 \quad$ Study design and interventions

60 This was a real-world, prospective observational cohort study comparing RADT to PCR, from

61 January $25^{\text {th }}$ to June $10^{\text {th }}, 2021$.

63 The lateral flow immunoassay [PanBio ${ }^{\mathrm{TM}}$ COVID-19 Ag test (Abbott Laboratories, Illinois,

64 USA)], authorised by Health Canada (22) was used. Nasal swabs were self-collected under the

65 supervision of a research assistant, to avoid sampling bias, who then performed RADT on site.

66 Spring water gargle specimens were collected for PCR testing (23). Laboratory-developed PCR

67 was performed at CHU Sainte-Justine, with a LOD of 400 copies/mL (24). Extraction and

68 purification of genetic material was done with Roche's MagNA Pure 96 system. The laboratory

69 testing protocol and the water gargle validation have been described elsewhere (25-28). 
medRxiv preprint doi: https://doi.org/10.1101/2021.10.13.21264960; this version posted January 23, 2022. The copyright holder for this preprint (which was not certified by peer review) is the author/funder, who has granted medRxiv a license to display the preprint in perpetuity.

It is made available under a CC-BY-NC-ND 4.0 International license .

70 Decisions about management of cases and contacts were made by two members of the research

71 team (AB, CQ), in collaboration with local public health (CT, OS). The school principals (YP,

72 DB) were actively involved in the study deployment.

73

74 1) Testing protocol in the absence of a known exposure:

75 a. Asymptomatic individuals: Nasal swabs and gargle specimens were collected weekly

76 for RADT (nasal) and PCR (gargle) on a random sample of $25 \%$ of participants,

$77 \quad$ stratified by class.

78 b. Symptomatic individuals: Gargle specimens for PCR and a nasal swab for RADT and PCR were performed on site. Results from RADT and PCR were reported to public health; an individual was considered infected if the PCR result was positive. If symptoms occurred in school, the research team proceeded with testing. If symptoms

84 2) Management of exposed contacts of a positive individual in a class

85 Contacts of a confirmed positive individual were isolated at home. Students were allocated to a

86 7- or 14-day quarantine, staffs were allocated to a 7-day quarantine, with tests (nasal RADT and

87 gargle PCR) three days after last contact with the known positive case, and up to two days before

88 the end of quarantine. RADT was performed on day (D)14, D21 and D28, if the initial PCR was

89 negative. If symptoms developed, both the RADT and PCR were performed. Students who did

90 not consent to the study were quarantined for 14 days. Students and staff with significant off-

91 campus exposures were offered on site testing.

92 


\section{Outcomes}

94 The primary outcome was to assess the performance characteristics of RADT in: a)

95 asymptomatic participants randomly screened; b) asymptomatic close contacts of a confirmed

96 positive case; c) symptomatic participants.

98 Secondary outcomes included: a) number of positive students by RADT in groups exposed to a 99 confirmed positive index case, allocated to early (on D8) versus standard (on D15) return to

100 school and b) number of case clusters in schools. This was compared to clusters in other high 101 schools in Montréal during the same time frame, using public health data.

103 Statistical analysis

104 Descriptive statistics were used for the performance of the RADT. To determine the precision 105 with which we could estimate our primary outcome, we implemented an agent-based model 106 (ABM) (29) (Supplementary Appendix A). Based on this simulation, we expected that the 107 number of infections and tests would be sufficient in one school but added a second school to 108 support generalizability of the findings and explore secondary objectives.

\section{Ethical considerations}

111 This project was approved by the CHU Ste-Justine Research Ethics Board (\#MP-21-2021-3271).

112 Informed parental consent or assent were required for all students. Parents who preferred to keep

113 their children home for 14 days in case of a contact could do so. Tests results were 114 communicated to parents and students by the school. This study was funded by the Québec 115 Ministry of Health and Social Services. 


\section{Results}

117 During the study period, 2,099 students and 286 school staff members consented to participate.

118 The participation rate for students was $78.5 \%$ and $63.5 \%$ (Figure 1) and $94.4 \%$ and $89.5 \%$ for

119 staff.

121 RADT results and PCR validation (from gargle specimens only)

$122 \quad$ 1) Asymptomatic students and staff

123 Of 5,583 RADT done on asymptomatic students (Table 1), seven had an invalid PCR result on

124 the gargle sample, seven were equivocal and three were weak positive, of which one was 125 negative when repeated the next day (and was excluded). Two students with equivocal or weak 126 positive PCR results had a positive PCR result in the previous 90 days. The prevalence in 127 asymptomatic participants was $0.30 \%$ (95\% CI 0.18- 0.49). Therefore, the sensitivity of RADT 128 in that population was $41.2 \%$ (95\% CI 21.6-64.0), with a specificity of $100.0 \%$.

130 Of 784 asymptomatic RADT screening tests done on asymptomatic randomly screened staff 131 members, two gave invalid PCR results and six were lost. Only one RADT was positive, but the 132 PCR was negative on both the gargle and nasal specimens, giving a specificity of $99.8 \%$ (95\% CI 133 99.3-100.0) (Table 1).

2) Asymptomatic exposed contacts in a classroom

136 A total of 1491 RADT tests and PCR were done on asymptomatic students exposed to a positive 137 classmate index case at D3 and 2 days before returning to class. After excluding one equivocal 138 PCR result, SARS-CoV-2 prevalence in this exposed group was $0.7 \%$ (95\% CI 0.5-1.6). The 
medRxiv preprint doi: https://doi.org/10.1101/2021.10.13.21264960; this version posted January 23, 2022. The copyright holder for this preprint (which was not certified by peer review) is the author/funder, who has granted medRxiv a license to display the preprint in perpetuity.

It is made available under a CC-BY-NC-ND 4.0 International license .

sensitivity of RADT was $28.6 \%$ (95\% CI 8.4-58.1) with a specificity of $99.6 \%$ (95\% CI 99.1-

140 99.9) (Table 1). Of 627 RADT done for asymptomatic exposed contacts on D14, D21 and D28,

141 only one was positive (also positive by PCR when tested on D12 - see below). A total of 61

142 RADT and PCR were done for staff members on D3 and D7 after a contact with a positive index

143 case in school (Table 1). All were negative.

3) Symptomatic students and staff

146 Overall, 235 students developed symptoms and were tested on site for SARS-CoV-2. As shown

147 in Table 1,10 had a positive RADT and 12 had a positive PCR [prevalence=5.1\% (95\% CI 2.7-

148 8.7)]. The sensitivity of RADT in that population was 83.3\% (95\% CI 51.6-97.9) with a 149 specificity of $100.0 \%$ (95\% CI 98.4-100.0). Sixty-four staff members were tested on site for

150 symptoms compatible with COVID-19. Only one had a positive RADT and PCR. One positive 151 case was identified by PCR after a negative RADT (sensitivity of 50\% (95\% CI 1,3- =98,7) and 152 specificity of $100 \%$.

154 Outbreaks and comparison with other schools in the region

155 We identified 76 PCR (gargle or nasal) positive cases, including three cases in staff. Of the 35 156 classes included in the study, 20 returned on D8 after contact, if the gargle PCR was negative on 157 D6 or D7.

159 Secondary cases were identified in 10 classes. The number of secondary cases in each class were 160 one ( $\mathrm{n}=8$ classes), three ( $\mathrm{n}=1$ class) and four $(\mathrm{n}=1$ class). Four secondary cases had a positive 161 RADT, including three asymptomatic students and one symptomatic student who tested positive 
medRxiv preprint doi: https://doi.org/10.1101/2021.10.13.21264960; this version posted January 23, 2022. The copyright holder for this preprint (which was not certified by peer review) is the author/funder, who has granted medRxiv a license to display the preprint in perpetuity.

It is made available under a CC-BY-NC-ND 4.0 International license .

162 by RADT and PCR on D12, with symptoms starting on D9 after last contact with the positive

163 classmate - a community exposure was also suspected. No tertiary case occurred. Outbreaks

164 were limited to the classroom bubble and to school friends seen outside of school. When the

165 source was known, 37/57 cases (72.5\%) were secondary to household transmission, 13 (25\%) to

166 intra-school transmission and one to community contacts between students in the same school.

167

168 During the same period, outbreaks declared in other Montreal schools had a lower proportion of

169 asymptomatic cases (31.8\%) compared to ESCL (55.6\%) and PSNM (85.7\%) (Supplementary

170 Appendix B).

171

172 Discussion

173 RADT were purchased worldwide as a tool to prevent outbreaks. However, their use is limited

174 by the paucity of evidence regarding their performance in children. In this study, we 175 prospectively compared the performance of a RADT to PCR for the purpose of limiting

176 transmission of SARS-CoV-2 infection in schools. In a context of lower SARS-CoV-2

177 prevalence in school than in the community (30), we observed only seven false positive RADT

178 during the 5-month study (all in asymptomatic individuals) and the specificity of the RADT

179 remained overall excellent. However, the sensitivity was much lower, varying between $28.6 \%$ in

180 asymptomatic to $83.3 \%$ in symptomatic students.

182 A recent large observational study described the use of RADT in asymptomatic individuals as

183 beneficial, reporting a sensitivity of $64.4 \%$ (95\% CI 58.3-70.2) (31). However, this could be

184 overestimated as not all asymptomatic individuals had a confirmatory PCR. In our study, only a 
medRxiv preprint doi: https://doi.org/10.1101/2021.10.13.21264960; this version posted January 23, 2022. The copyright holder for this preprint (which was not certified by peer review) is the author/funder, who has granted medRxiv a license to display the preprint in perpetuity.

It is made available under a CC-BY-NC-ND 4.0 International license.

185 few positive cases were detected by RADT (overall 7/6358, 0.11\%) in asymptomatic individuals

186 who were randomly tested. Ten additional cases were detected by PCR from gargle specimens.

187 Two full-time research assistants were in each school, in addition to local school staff who were

188 supporting the study rollout. This level of required resources goes against the use of RADT for

189 random screening of asymptomatic individuals, given low sensitivity in that setting.

190

191 RADT detected SARS-CoV-2 positive symptomatic cases in 15 minutes, allowing for prompt

192 isolation, contact tracing and testing. The overall sensitivity of RADT in symptomatic

193 individuals was 78.6\% (95\% CI 49.2-95.3). This finding is in agreement with other published

194 studies $(14,15,32-34)$. Sood et al. recently described that the positive concordance of RADT

195 was higher among symptomatic children (64.4\%) compared to asymptomatic children (51.1\%)

196 presenting at a walk-in testing site (33). L'Huillier et al. described a sensitivity of $73.0 \%$ in

197 symptomatic vs. $43.3 \%$ in asymptomatic children (34). The authors described the peak of

198 sensitivity on D2 post symptoms onset, with a subsequent decrease to $56 \%$ by D5. In our study,

199225 of 235 symptomatic children had recorded their symptoms onset, with a median time of one

200 day (range: 0-33 days). Overall, 46.7\% ( $n=105 / 225)$ were tested with RADT and PCR on the day

201 of symptoms onset. Our reported RADT sensitivity may have been higher had students been

202 tested on subsequent days. However, the usefulness of RADT is to control outbreaks, therefore

203 delaying testing to enhance sensitivity would be counterproductive. This trade-off may not apply

204 to the Delta variant, for which the kinetic of infection may differ $(35,36)$.

205

206 RADT identified $28.6 \%$ of positive asymptomatic exposed school contacts, which was similar to

207 that recently described by Torres et al. for non-household significant contacts (sensitivity: 
medRxiv preprint doi: https://doi.org/10.1101/2021.10.13.21264960; this version posted January 23, 2022. The copyright holder for this preprint (which was not certified by peer review) is the author/funder, who has granted medRxiv a license to display the preprint in perpetuity.

It is made available under a CC-BY-NC-ND 4.0 International license .

$35.7 \%$ ) (37). Although this percentage is low, the rapid diagnosis of SARS-CoV-2 infection in exposed individuals allowed local public health to quickly manage these students' household contacts who, at the time, had to isolate until the result of the D3 testing. With changes in

211 quarantine recommendations for vaccinated family members, the benefit of RADT in this group

212 may be smaller. Most positive cases in students were due to household SARS-CoV-2

213 transmission. Students were often sent to school despite having a known positive contact. Active

214 screening of symptoms and history of significant exposures should be reinforced to prevent

215 school outbreaks. Thirteen of 51 cases were acquired from school, with 15 cases in the same

216 class bubble (in five classes overall). Therefore, the asymptomatic nature of this infection makes

217 screening for school contacts essential. Our results demonstrate that using a more sensitive

218 method, such as PCR, may be more reliable for that purpose.

220 This study had several limitations. We did not collect data regarding adherence to public health

221 measures, nor systematically documented exposures occurring outside of school. However, for

222 the most part, we were able to identify when significant household transmission occurred and

223 relied on the transparency of participants. We cannot infer whether PCR positive individuals

224 were contagious. The study was performed before the advent of the Delta variant in our region.

225 Because RADT detects the N protein, we expect that its sensitivity and specificity would not be

226 affected negatively, as viral loads of Delta variant infections are reported to be higher (35).

227 Recently published data indicates that the performance of the PanBio ${ }^{\mathrm{TM}}$ RADT is similar for

228 detection of the Delta variant than for other variants (38). Despite vaccination, transmission of

229 SARS-CoV-2 is occurring in schools, therefore the findings of this study related to the use of

230 RADT to prevent outbreaks are valid and relevant. Finally, the sensitivity of RADT in 
medRxiv preprint doi: https://doi.org/10.1101/2021.10.13.21264960; this version posted January 23, 2022. The copyright holder for this preprint (which was not certified by peer review) is the author/funder, who has granted medRxiv a license to display the preprint in perpetuity.

It is made available under a CC-BY-NC-ND 4.0 International license .

231 symptomatic individuals was based on a relatively small number of people with PCR-confirmed

232 SARS-CoV-2 infection.

233

234 This is the largest study to date assessing the use of RADT in schools. The strengths of this study

235 included its prospective design and the real-world use of RADT versus PCR. We assigned

236 participants to earlier versus standard return to school with serial RADT, showing that there were

237 no secondary outbreaks with shorter quarantine. Although the study was not powered to rule this

238 out, this aligns with other recently published data (39) and may allow policymakers to consider

239 reducing the duration of quarantine for exposed contacts, provided a PCR is negative on D6 or

240 D7.

242 In conclusion, our findings contribute to the growing evidence that the use of RADT leads to

243 rapid diagnosis of SARS-CoV-2 infection in symptomatic individuals (40). However, RADT

244 does not perform as well as a screening tool in asymptomatic individuals. In our study, teenagers

245 were able to proceed to self-collection of swabs, while supervised by a research assistant. It may

246 be helpful to reinforce policies for symptom screening when entering schools, where

247 symptomatic individuals could be tested with RADT to avoid significant in-class exposures . A

248 negative RADT could still mean that symptoms are due to SARS-CoV-2, but with a viral load

249 too low to be detected and therefore less likely to transmit at that point. In such instance, a

250 subsequent sample tested by PCR would be useful. 


\section{References}

1. Hellewell J, Abbott S, Gimma A, Bosse NI, Jarvis CI, Russell TW, et al. Feasibility of controlling COVID-19 outbreaks by isolation of cases and contacts. Lancet Glob Health. 2020;8(4):e488-e96.

2. Kretzschmar ME, Rozhnova G, Bootsma MCJ, van Boven M, van de Wijgert J, Bonten MJM. Impact of delays on effectiveness of contact tracing strategies for COVID-19: a modelling study. Lancet Public Health. 2020;5(8):e452-e9.

3. Azar MM, Landry ML. Detection of Influenza A and B Viruses and Respiratory Syncytial Virus by Use of Clinical Laboratory Improvement Amendments of 1988 (CLIA)Waived Point-of-Care Assays: a Paradigm Shift to Molecular Tests. J Clin Microbiol. 2018;56(7).

4. C AH, Caya C, Papenburg J. Rapid and simple molecular tests for the detection of respiratory syncytial virus: a review. Expert Rev Mol Diagn. 2018;18(7):617-29.

5. Chartrand C, Tremblay N, Renaud C, Papenburg J. Diagnostic Accuracy of Rapid Antigen Detection Tests for Respiratory Syncytial Virus Infection: Systematic Review and Metaanalysis. J Clin Microbiol. 2015;53(12):3738-49.

6. Papenburg J, Buckeridge DL, De Serres G, Boivin G. Host and viral factors affecting clinical performance of a rapid diagnostic test for respiratory syncytial virus in hospitalized children. J Pediatr. 2013;163(3):911-3.

7. Peeling RW, Olliaro PL, Boeras DI, Fongwen N. Scaling up COVID-19 rapid antigen tests: promises and challenges. Lancet Infect Dis. 2021.

8. Ma Z, Idris S, Zhang Y, Zewen L, Wali A, Ji Y, et al. The impact of COVID-19 pandemic outbreak on education and mental health of Chinese children aged 7-15 years: an online survey. BMC Pediatr. 2021;21(1):95.

9. Koirala A, Wood N, Macartney K. Testing for SARS-CoV-2 infection: a key strategy to keeping schools and universities open. Lancet Child Adolesc Health. 2021;5(6):387-9.

10. Engzell P, Frey A, Verhagen MD. Learning loss due to school closures during the COVID-19 pandemic. Proc Natl Acad Sci U S A. 2021;118(17).

11. Learning during the pandemic: review of international research. Government of the United Kingdom. 12 July 2021. [Available from: https://www.gov.uk/government/publications/learning-during-the-pandemic/learning-during-thepandemic-review-of-international-research\#authors (Accessed 7-9-2021).

12. Centers for Disease Control and Prevention. Interim Guidance for Antigen Testing for SARS-CoV-2. $\quad$ https://www.cdc.gov/coronavirus/2019-ncov/lab/resources/antigen-testsguidelines.html (Accessed 7-8-2021).

13. Government of Canada. Interim guidance on the use of rapid antigen detection tests for the identification of SARS-CoV-2 infection. https://www.canada.ca/en/publichealth/services/diseases/2019-novel-coronavirus-infection/guidance-documents/use-rapidantigen-detection-tests.html (accessed 7-8-2021).

14. Pickering S, Batra R, Merrick B, Snell LB, Nebbia G, Douthwaite S, et al. Comparative performance of SARS-CoV-2 lateral flow antigen tests and association with detection of infectious virus in clinical specimens: a single-centre laboratory evaluation study. Lancet Microbe. 2021. 
15. Wagenhauser I, Knies K, Rauschenberger V, Eisenmann M, McDonogh M, Petri N, et al. Clinical performance evaluation of SARS-CoV-2 rapid antigen testing in point of care usage in comparison to RT-qPCR. EBioMedicine. 2021;69:103455.

16. Dinnes J, Deeks JJ, Berhane S, Taylor M, Adriano A, Davenport C, et al. Rapid, point-ofcare antigen and molecular-based tests for diagnosis of SARS-CoV-2 infection. Cochrane Database Syst Rev. 2021;3:CD013705.

17. Hayer J, Kasapic D, Zemmrich C. Real-world clinical performance of commercial SARSCoV-2 rapid antigen tests in suspected COVID-19: A systematic meta-analysis of available data as of November 20, 2020. Int J Infect Dis. 2021;108:592-602.

18. Mertens P, De Vos N, Martiny D, Jassoy C, Mirazimi A, Cuypers L, et al. Development and Potential Usefulness of the COVID-19 Ag Respi-Strip Diagnostic Assay in a Pandemic Context. Front Med (Lausanne). 2020;7:225.

19. Kawasuji H, Takegoshi Y, Kaneda M, Ueno A, Miyajima Y, Kawago K, et al. Transmissibility of COVID-19 depends on the viral load around onset in adult and symptomatic patients. PLoS One. 2020;15(12):e0243597.

20. Shenoy S. SARS-CoV-2 (COVID-19), viral load and clinical outcomes; lessons learned one year into the pandemic: A systematic review. World J Crit Care Med. 2021;10(4):132-50.

21. Brandolini M, Taddei F, Marino MM, Grumiro L, Scalcione A, Turba ME, et al. Correlating qRT-PCR, dPCR and Viral Titration for the Identification and Quantification of SARS-CoV-2: A New Approach for Infection Management. Viruses. 2021;13(6).

22. Government of Canada. Interim guidance for the detection of SARS-CoV-2 with the Abbott Panbio COVID-19 antigen rapid test. https://www.canada.ca/en/publichealth/services/reports-publications/canada-communicable-disease-report-ccdr/monthlyissue/2021-47/issue-1-january-2021/interim-guidance-detection-sars-cov-2-abbott-panbioantigen-rapid-test.html (Accessed 7-8-2021).

23. Goldfarb DM, Tilley P, Al-Rawahi GN, Srigley JA, Ford G, Pedersen H, et al. SelfCollected Saline Gargle Samples as an Alternative to Health Care Worker-Collected Nasopharyngeal Swabs for COVID-19 Diagnosis in Outpatients. J Clin Microbiol. 2021;59(4).

24. Corman VM, Landt O, Kaiser M, Molenkamp R, Meijer A, Chu DK, et al. Detection of 2019 novel coronavirus (2019-nCoV) by real-time RT-PCR. Euro Surveill. 2020;25(3).

25. Benoit P, Labbe AC, Lalancette L, Gagnon S, Bonneau E, Lavallee C, et al. Comparison of SARS-CoV-2 detection with the Cobas(R) 6800/8800 system on gargle samples using two sample processing methods with combined oropharyngeal/nasopharyngeal swab. J Med Virol. 2021.

26. Dumaresq J, Coutlée F, Dufresne PJ, Longtin J, Fafard J, Bestman-Smith J, et al. Natural spring water gargle and direct RT-PCR for the diagnosis of COVID-19 (COVID-SPRING study). Journal of Clinical Virology. 2021;144:104995.

27. Paré SG. B-SJ, Fafard J. et al. Natural spring water gargle samples as an alternative to nasopharyngeal swabs for SARS-CoV-2 detection using a laboratory-developed test. Submitted. 2021.

28. Boutin CA, Grandjean-Lapierre S, Gagnon S, Labbé AC, Charest H, Roger M, et al. Comparison of SARS-CoV-2 detection from combined nasopharyngeal/oropharyngeal swab samples by a laboratory-developed real-time RT-PCR test and the Roche SARS-CoV-2 assay on a cobas 8800 instrument. J Clin Virol. 2020;132:104615. 
medRxiv preprint doi: https://doi.org/10.1101/2021.10.13.21264960; this version posted January 23, 2022. The copyright holder for this preprint (which was not certified by peer review) is the author/funder, who has granted medRxiv a license to display the preprint in perpetuity. It is made available under a CC-BY-NC-ND 4.0 International license .

29. Phillips B, Browne DT, Anand M, Bauch CT. Model-based projections for COVID-19 outbreak size and student-days lost to closure in Ontario childcare centres and primary schools. Sci Rep. 2021;11(1):6402.

30. Government of Québec. Situation of COVID-19 in Montreal. [Available from: https://santemontreal.qc.ca/en/public/coronavirus-covid-19/situation-of-the-coronavirus-covid19-in-montreal/ (Accessed 4-10-2021).

31. Wachinger J, Olaru ID, Horner S, Schnitzler P, Heeg K, Denkinger CM. The potential of SARS-CoV-2 antigen-detection tests in the screening of asymptomatic persons. Clin Microbiol Infect. 2021.

32. Mockel M, Corman VM, Stegemann MS, Hofmann J, Stein A, Jones TC, et al. SARSCoV-2 antigen rapid immunoassay for diagnosis of COVID-19 in the emergency department. Biomarkers. 2021;26(3):213-20.

33. Sood N, Shetgiri R, Rodriguez A, Jimenez D, Treminino S, Daflos A, et al. Evaluation of the Abbott BinaxNOW rapid antigen test for SARS-CoV-2 infection in children: Implications for screening in a school setting. PLoS One. 2021;16(4):e0249710.

34. L'Huillier AG, Lacour M, Sadiku D, Gadiri MA, De Siebenthal L, Schibler M, et al. Diagnostic accuracy of SARS-CoV-2 rapid antigen detection testing in symptomatic and asymptomatic children in the clinical setting. J Clin Microbiol. 2021:JCM0099121.

35. Bolze A, Cirulli ET, Luo S, White S, Wyman D, Rossi AD, et al. SARS-CoV-2 variant Delta rapidly displaced variant Alpha in the United States and led to higher viral loads. medRxiv. 2021:2021.06.20.21259195.

36. Li B, Deng A, Li K, Hu Y, Li Z, Xiong Q, et al. Viral infection and transmission in a large, well-traced outbreak caused by the SARS-CoV-2 Delta variant. medRxiv. 2021:2021.07.07.21260122.

37. Torres I, Poujois S, Albert E, Colomina J, Navarro D. Evaluation of a rapid antigen test (Panbio COVID-19 Ag rapid test device) for SARS-CoV-2 detection in asymptomatic close contacts of COVID-19 patients. Clin Microbiol Infect. 2021;27(4):636 e1- e4.

38. Bekliz M, Adea K, Essaidi-Laziosi M, Sacks JA, Escadafal C, Kaiser L, et al. SARSCoV-2 rapid diagnostic tests for emerging variants. Lancet Microbe. 2021;2(8):e351.

39. Nelson EJ, McKune SL, Ryan KA, Lednicky JA, Crowe SR, Myers PD, et al. SARSCoV-2 Positivity on or After 9 Days Among Quarantined Student Contacts of Confirmed Cases. JAMA. 2021;325(15):1561-2.

40. Ciaranello A, Goehringer C, Nelson SB, Ruark LJ, Pollock NR. Lessons Learned From Implementation of SARS-CoV-2 Screening in K-12 Public Schools in Massachusetts. Open Forum Infect Dis. 2021;8(8):ofab287. 
Table 1. Performance of RADT in the different participant groups

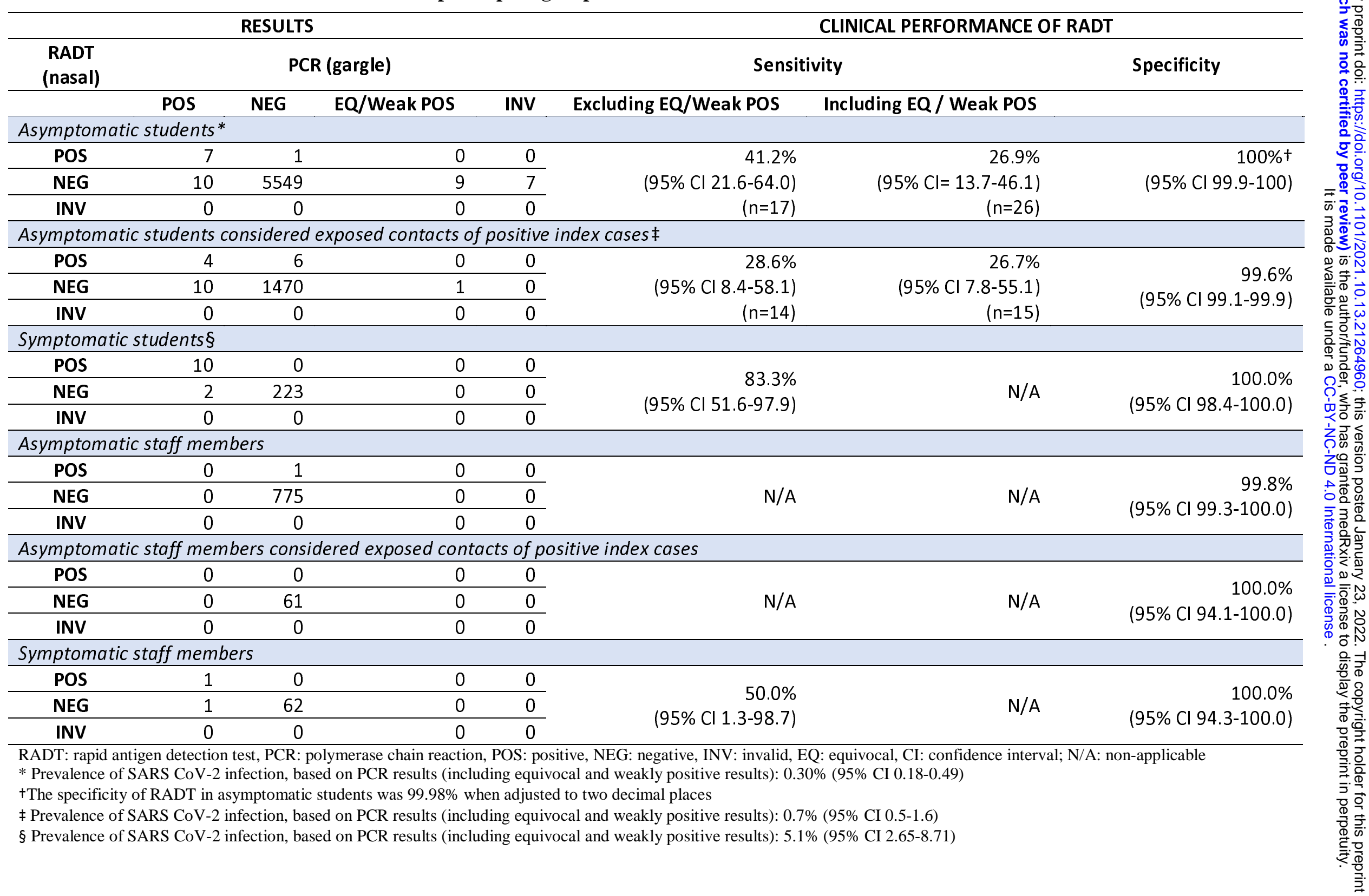


Figure 1: Proportion of participating students per class and level

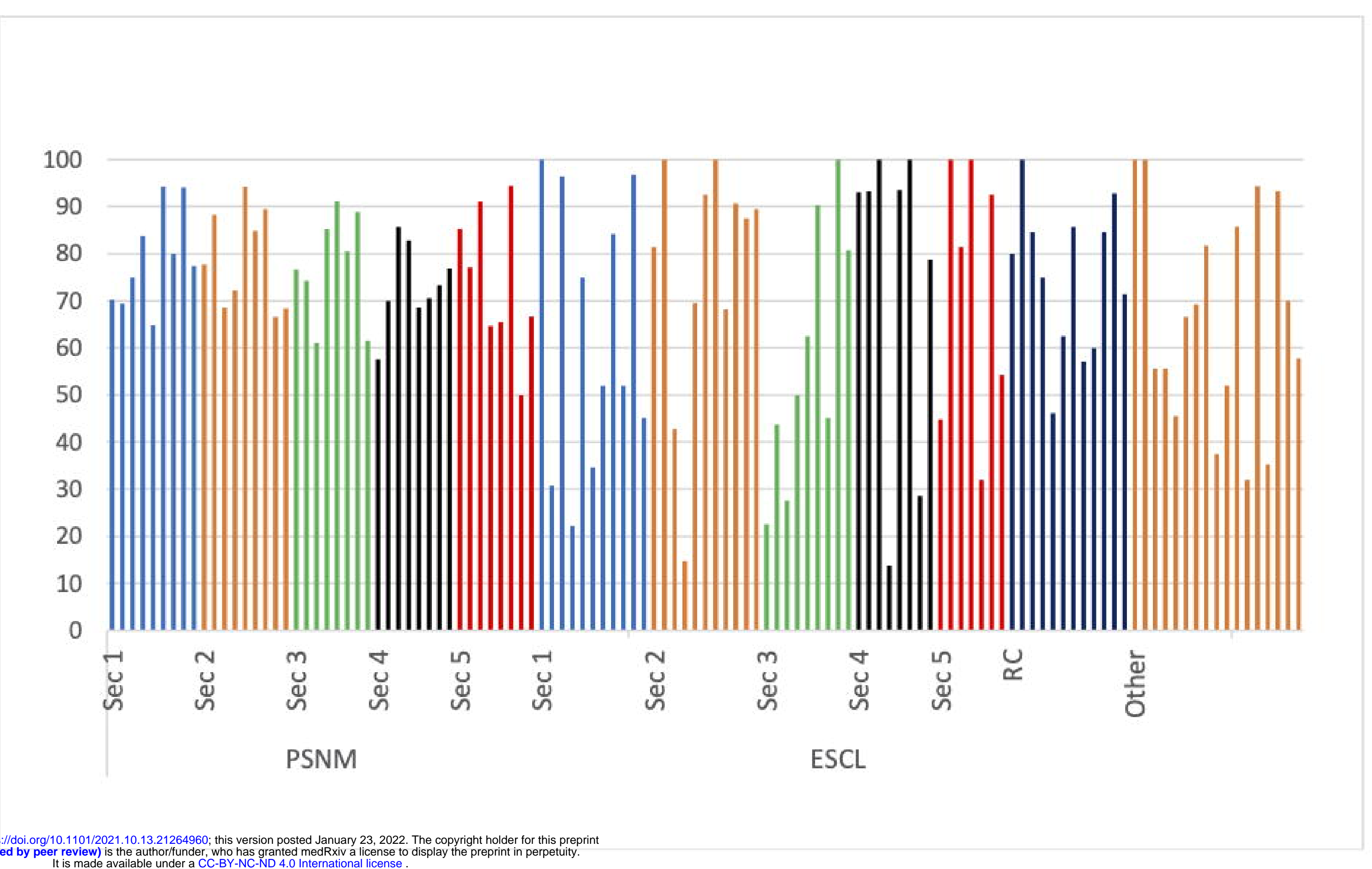

Sec: Secondary; RC: Reception class; PSNM: Pensionnat du Saint-Nom-de-Marie; ESCL : École Secondaire Calixa-Lavallée. 